\section{DAIRY PRODUCTS}

\section{A THESIS}

Presented to the Faculty of the Graduate School of Cornell UntVhersity for the Degree of DOCTOR OF PHILOSOPHY

BY

EDWARD SEWALL GUTHRIE

A Bulletin from the Agricultural Experiment Station of the New York State College of Agriculture 



\section{METALLIC FLAVOR IN DAIRY PRODUCTS}

\section{A THESIS}

Presented to the Faculty of the Graduate School of Cornell University for the Degree of DOCTOR OF PHILOSOPHY

BY

EDWARD SEWALL GUTHRIE

A Bulletin from the Agricultural Experiment Station of the New York State College of Agriculture 


$$
\begin{array}{r}
5 F^{40} \\
685
\end{array}
$$

\section{In Exchange.}

Conell Unio. DEC $4-1916$

$$
\therefore \vdots
$$




\section{CONTENTS}

General observations. . . . . . . . . . . . . . . . . . . . . . . . 6 I0

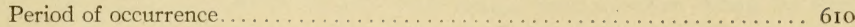

Causes of metallic flavor . . . . . . . . . . . . .

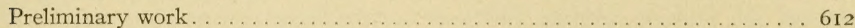

Work of other investigators . . . . . . . . . . . . $6 \ldots \ldots \ldots$

Nature of medium having metallic flavor in the greatest degree...........6I5

Factors affecting development of metallic flavor . . . . . . . . . . . . . . . 6

Relation of fat content to metallic flavor . . . . . . . . . . . . $6 \ldots$

Relation of acidity to metallic flavor . . . . . . . . . . . . $6 \ldots \ldots$

Temperature in relation to metallic flavor . . . . . . . . . . . . . . 6 I $7_{7}$

Effect of cooked flavor in relation to metallic flavor . . . . . . . . . . 6 I 7

Method of obtaining a medium for detection of metallic flavor . . . . . . . . . 6r 7

Bacteria in some metallic-flavored dairy products . . . . . . . . . . . . . 6 9

Formaldehyde and metallic flavor. . . . . . . . . . . . . . . . . . . 620

Effect of adding pure lactic acid to some dairy products . . . . . . . . . . . .

Relation of enzymic growth to metallic'flavor . . . . . . . . . . . . . . . .

Number of bacteria in buttermilk before and after development of metallic flavor. 622

A qualitative study of the bacteria in fresh and in metallic-flavored buttermilk...6 623

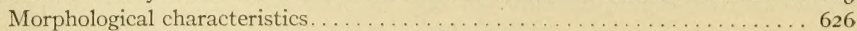

Cultural characteristics . . . . . . . . . . . . . . . . . . . . . . 626

Conclusions. . ................................. 627

Bibliography . . . . . . . . . . . . . . . . . . . . . . . . . . . . . . . . . . . . . . 628

Appendix (containing tables) . . . . . . . . . . . . . . . . . . . . . . . 629 



\title{
METALLIC FLAVOR IN DAIRY PRODUCTS
}

\author{
E. S. Guthrie
}

The sale of dairy products depends largely on their flavor. Many flavors do not materially affect the sale of dairy goods, but, on the other hand, there are several that directly affect their price. Metallic flavor belongs to the latter class, and may reduce the price of butter from one to two cents a pound.

Metallic flavor as such was not of great importance until about twelve years ago. So far as the writer is able to determine, the first person to detect this flavor was B. D. White, who states that in I90I, when he was an assistant commissioner on the Dairy and Food Commission of Minnesota, that commission instituted a monthly scoring contest for butter in conjunction with the Minnesota Agricultural School. In this contest Mr. White criticized the butter, explaining any abnormal flavors or defects found. Various flavors were detected, among them a new flavor, which was designated as metallic, a curdy flavor, and a feverish, or cowy, flavor. It was noticed later, after publication of those criticisms, that other States had adopted the same terms in criticizing butter, and the question was whether the same flavors were recognized or whether the terms were applied to other flavors. Later, however, in monthly scoring contests conducted by the National Creamery Buttermakers' Association in connection with the United States Department of Agriculture, in which Mr. White was critic, the same terms were used, and in that way they were carried through the United States rather thoroughly and the various judges who attended the different scorings became familiar with them.

The character of metallic flavor has been determined through personal correspondence with noted authorities on butter in this country, and with one expert in Denmark, one of the greatest butter countries in the world. These men are as follows: Professor Bernhard Boggild, Royal Veterinary and Agricultural College, Copenhagen, Denmark; F. W. Bouska, formerly professor of dairy bacteriology at Iowa State College, now with the Beatrice Creamery Company, Lincoln, Nebraska; C. E. Croomer, manager of the butter department of the Fox River Butter Company, Chicago, Illinois; C. W. Fryhofer, formerly federal butter expert on the New York City market, now in the Dairy Division of the United States Bureau of Animal Industry; Professor N. W. Hepburn, University of Illinois; J. C. Joslin, formerly federal butter expert on the Chicago market; P. H. Kieffer, President of the Gude Brothers Kieffer Company, New York City; Professor C. Larsen, South Dakota State College and Experiment Station; 
Professor C. E. Lee, University of Wisconsin; Robert McAdam, formerly in charge of renovated butter inspection, Dairy Division, United States Bureau of Animal Industry; G. L. McKay, formerly professor of dairying at Iowa State College, now secretary of the American Association of Creamery Butter Manufacturers; Professor M. Mortensen, Iowa State College; Professor A. B. Nystrom, State College of Washington; S. E. Thompson, in charge of dairy manufacturing investigations, Dairy Division, United States Bureau of Animal Industry; B. D. White, formerly in charge of dairy manufacturing investigations, Dairy Division, United States Bureau of Animal Industry; Professor J. H. Frandsen, University of Nebraska; H. J. Credicott, formerly federal butter inspector on the Chicago market.

According to Fryhofer, Kieffer, Hepburn, McKay, Lee, Thompson, and Nystrom, metallic flavor is similar to the flavor of rusty iron. Lee, Croomer, Thompson, and Fryhofer state that there is a similarity between fishy flavor and metallic flavor. Thompson says: "It is classified as fishy, oily, tallowy, etc. I believe, however, that it is safe to say that the true metallic flavor is easily recognized by men qualified to judge of such things, after they have once become familiar with it."

The detection of metallic flavor is difficult. In order to determine whether there is any uniformity of judgment as to this flavor, the writer took a sample of butter pronounced metallic by the butter judges of the Department of Dairy Industry at Cornell University, to the National Dairy Show, for the criticism of some of the experts already named. It was inspected by McKay, Larsen, Thompson, Kieffer, Joslin, Lee, Hepburn, Frandsen, and Credicott. Every one of these men said that without doubt the flavor was metallic. In each of the criticisms, more than one judge examined and criticized the product. In case only two judges were present, and one reported in the affirmative while the other decided in the negative, the result was counted as negative. But if there were four judges, and two pronounced the flavor metallic while the other two reported it not metallic, the sample was counted as metallic, with one exception. There was no particular reason for this decision, aside from the fact that if two judges found metallic flavor it would seem that it must be present in a slight degree. When three or five judges made the examination, the majority report was taken.

\section{GENERAL OBSERVATIONS}

PERIOD OF OCCURRENCE

Croomer and Larsen claim that metallic flavor in butter is found oftenest in early spring and late fall; Kieffer and McAdam say that it is commonest 
in late fall and winter; Hepburn, McKay, and Fryhofer say that it is commonest during the hottest time of the year; and Nystrom observes that it is commonest in the fall. Thompson says: "The extent or frequency with which this trouble occurs, I am unable to determine. It is apparently confined to no particular section or season, but may occur anywhere and at any time." This last opinion - that is, that metallic flavor " may occur anywhere and at any time" - is supported by Croomer, Hepburn, McKay, Larsen, and Fryhofer.

\section{CAUSES OF METALLIC FLAVOR}

Joslin and McKay think that pasteurization is a factor in the production of metallic flavor in butter. Mortensen and Melick (I9I 2$)^{1}$ on the other hand, claim that if pasteurization is properly done it prevents the development of the flavor.

Thompson, Fryhofer, McKay, Joslin, White, and the New York Produce Review and American Creamery (I9I2), state that there seems to be a definite relationship between high acidity and metallic flavor.

White, McAdam, Croomer, and Kieffer think that metallic flavor is due directly to metals.

Brown (I912) states that he has known the first of the two churnings from a ripener to come out with a fine flavor, and the next one, some two hours later and held at a temperature of $46^{\circ} \mathrm{F}$., to come out with a bad metallic flavor. He says that when there was any metallic flavor at all it was invariably the worse in the latter churning.

Melick (I9I2) observed that cream seemed to develop metallic flavor near its surface. He attributed this to certain atmospheric conditions, since no metallic flavor appeared when the vats were carefully closed.

Boggild writes: "We here in Denmark have for a long time known that the same or a similar taste [referring to the metallic flavor] in butter can be due to rusty utensils, and in some cases to bacteria, and also that the so-called fishy flavor is due to microorganisms."

Coinciding with Boggild's idea that a microorganism is the cause of fishy flavor, the New York Produce Review and American Creamery (I9I2) makes the following statement: "We will not attempt to assign causes for all flavors in butter resembling the 'metallic.' Doubtless such defects may have a bacterial origin as well as an origin actually associated with metals with which the more or less acid cream has come in contact."

The following extract is from Irish Homestead (19I3):

In some Irish creameries, particularly in those where pasteurization has been attempted, regardless of the percentage of fat in the cream, a flavor that somewhat resembled "fishiness" was experienced. Although it did not entirely coincide with "fishiness," the resemblance was close, but it may be more accurately described as

\footnotetext{
${ }^{1}$ Dates in parenthesis refer to bibliography, page 628 .
} 
a "metallic" flavor, possibly due to some organic cause. This flavor was invariably noticed in butter the cream of which contained over 35 per cent of fat, and it was particularly noticeable where the fat content in the cream ran over 40 per cent and up to 50 per cent, when the cream was pasteurized. In some cases the flavor was even noticeable where the whole milk was not heated beyond $130^{\circ} \mathrm{F}$, , and where the cream was not pasteurized.

It is, of course, evident that whether milk or cream is pasteurized, the cream for buttermaking should not contain more than 33 per cent of fat, and the results; particularly as regards the keeping qualities of the butter, are much more likely to be satisfactory where a thin cream, not containing over 30 per cent of butterfat, is separated and then thoroughly pasteurized, well cooled down, ripened at a moderately low temperature, with a liberal supply of clean, active starter to an acidity of 0.3 to 0.35 , but in no case exceeding 0.4 .

In the most progressive and highly successful dairying countries of Europe it is the general practice all through the year to separate a thin cream - in most cases the cream does not contain over 25 per cent of butterfat, while in one large dairying country the cream rarely contains over 20 per cent of butterfat, and pasteurization is general among all the creameries.

\section{PRELIMINARY WORK}

The observations on metallic flavor made in the laboratories at Cornell University were as follows:

I. High acid content seemed essential for the development of the flavor.

Every instance in which metallic flavor was found in the preliminary work was in a product of high acidity, and only twice did the writer hear of its being noted in sweet dairy products. In one case a milk company reported metallic flavor in sweet milk, but it was of short duration. The second case was reported by White, who wrote: "I have always found the metallic flavor in condensed milk and believe that this is due entirely to the raw copper of condensing pans." The writer has never noticed this flavor in condensed milk, nor has he detected it in swiss cheese, another dairy product made in a copper container.

The chemist would say that there is far greater probability of a metal's being absorbed by an acid solution than by a non-acid one. Nevertheless it is true that some dairy products of very high acidity have been held in containers with exposed surfaces of metals that easily combine with lactic acid to form lactates, such as copper and iron, and have not developed a metallic flavor that could be detected by expert judges of that flavor. The tin of the starter can in the butter laboratory at Cornell is almost entirely off. Starter has been cultivated daily in this can for three or four years; it has been carefully examined many times for metallic flavor, and this has been present in only a few cases.

It is possible that electrolytic action plays an important part in the production of metallic flavor when the source is directly from metal.

II. The flavor was most likely to appear during the hottest season.

It may be that this was noticeable because the degree of acidity of the product is likely to be greater when the temperature is high.

III. A high fat content seemed necessary for the development of the flavor, except in the case of buttermilk. 
These observations, which were made two years before the report of Irish Homestead already quoted was published, seemed to indicate that metallic flavor developed more rapidly and to a greater extent in cream that was rich in butterfat than in cream with a low fat content. The flavor was very strong in some samples of soft cream cheese, but was never noticed in cottage cheese, which contains practically no butterfat. Whenever the flavor was found in whole milk, it was always near the surface, in the cream, and it was never observed in skimmed milk. For some reason, however, it was often found in buttermilk. With the exception of buttermilk, metallic flavor was never found in a dairy product that was low in butterfat content.

IV. The flavor appeared spasmodically.

Often metallic flavor could not be detected in butter for several weeks, and sometimes for many months, after which it suddenly appeared for perhaps a few days, or possibly for several weeks. During all this time the same utensils were being used on the farms and in the creamery laboratories.

V. Low temperatures often seemed to make the flavor more apparent.

The low temperatures in the laboratories may have held in check certain organisms that at ligh temperatures produce sufficiently strong flavors to cover the metallic flavor.

The preliminary observations thus seemed to indicate that there may be a cause of metallic flavor other than direct contact of the dairy product with metal. In fact, it was quite apparent that there may be a biological reason for the development of metallic flavor, for in several instances it seemed to increase when the product was not in contact with metal.

\section{WORK OF OTHER INVESTIGATORS}

Some work has been done of a more scientific nature than that just described. The most recent is that of Rogers, Berg, Potteiger, and Davis (I9I3), who report, besides their own work, researches by several other investigators. The following abstract of their bulletin appeared in a press notice sent out by the United States Department of Agriculture:

Some metals either cause or greatly accelerate certain bad flavors in butter, although most of the experiments along this line have not included storage butters. Recently the scientific staff of the Dairy Division of the Bureau of Animal Industry in the United States Department of Agriculture has reported that the presence of very small amounts of iron in cream causes certain undesirable flavors to increase in intensity during storage. These flavors are often designated by butter experts as "metallic," "oily," or " fishy." The injurious effect of iron was found by adding iron in known quantities, varying from I to 500 parts, to $I, 000,000$ parts of cream. The butter made from such cream was compared with that made from cream where all precautions were taken to avoid any undue contact with iron during the whole process of butter-making. The butter was stored at $6^{\circ}$ to $10^{\circ} \mathrm{F}$, and the quality of the butter was scored by experts at different times. In every instance when the butter was scored a few days after making, the samples to which iron had been added scored lower than the butter made from cream which contained no iron. This held true in most cases on the second and third scoring, 
which occurred at intervals varying from 20 to 187 days. The most noticeable feature was the rapid development of bad flavor in the butter containing the jron. When both the control and the experimental butter became fishy it was noticed that the control butter was the last to become so. There was a marked oily flavor present in most samples that subsequently became fishy. Only a small proportion of the iron added to the cream was found in the butter, the remainder having been taken up by the buttermilk and wash water.

Butter was also made from cream which had stood in rusty cans, and in every case this butter had a peculiar taste and was easily picked out from all other samples. The buttermilk also had a decided metallic taste.

The influence of copper on the flavor of butter was studied in a similar manner, and it was found that copper, even in small quantities, seemed to cause more marked changes of flavor in butter than did the iron, with a decided tendency toward a fishy flavor in storage. Two experiments showed very plainly the harmful effect of using poorly tinned pasteurizers, even though the cream came in contact with the copper surface for only a few seconds, for, aside from this, all other conditions were exactly alike during the complete process of butter manufacture.

This work shows that if cream is kept in rusty cans or comes in contact with iron or copper at any time during the process of butter-making it may take up iron or copper from rusty cans, exposed bolt heads. or other metal parts of pasteurizers or churns, in sufficient quantities to affect the flavor of storage butter. Though there is nothing to show that the nature of the flavor is appreciably changed, it does demonstrate very clearly that the rate of development of the undesirable flavor is greatly accelerated during storage by very small quantities of either iron or copper.

\section{Golding and Feilmann (1905) think that microorganisms may be the} fundamental cause of metallic flavor. However, they attribute the cause largely to contact of the product with exposed surfaces of copper. They found that milk passed over an untinned copper cooler took up 2.5 parts of copper in $10,000,000$ parts of sweet milk, and, though the characteristic flavor was not at once apparent, it invariably was perceptible in about eightecn hours at room temperature. They observed that air aids greatly in the solution of copper in milk. Clean copper gauze fixed on the surface of some milk in a beaker and left for one week resulted in the solution of I 2 I parts of copper in $\mathrm{I}, 000,000$ parts of milk. At the bottom of the beaker only 48 parts per million were dissolved. They say:

The chemistry of the flavour is still only a matter of speculation, but similar flavours can be produced by other oxidising agents, such as potassium permanganate, ferric chloride and hydrogen peroxide.

A large number of organisms were isolated from the different samples of milk which had developed the characteristic flavour; but none of them developed the flavour in milk which had been sterilised by heat. When, however, the influence of the copper had been discovered, the experiments were repeated, and the flavor seemed to be developed by certain organisms, but was rather masked by the well-known taste of the sterilised milk.

The bacteriological investigations of a rather indefinite flavour, which is largely masked in heated milk, cannot be very satisfactory, but it seems certain that microorganisms are not without influence in some direct or indirect way.

In the discussion that followed this paper (read before the Society of Chemical Industry), H. Droop Richmond, a well-known English chemist, said that he had for some years thought the taste complained of was not due to copper, because it was some time before it came out; he believed it 
was due rather to microorganisms. The paper, however, showed that both were active agents. Mr. Richmond had succeeded in finding a liquefying microorganism which he had no doubt was similar to the one just shown by the authors. The metallic taste was found chiefly in winter, in milk that had been pasteurized; in summer it was not so marked, and neither was it so marked in the presence of a large number of lactic organisms. $\mathrm{Mr}$. Richmond succeeded in getting rid of the taste by finding where the organisms existed.

There seems to be no doubt, therefore, that metallic flavor is caused by the direct absorption of metal by milk or cream. It is apparent also that more or less work has been done, the results of which, coinciding with some of the general observations noted in preceding pages, indicate that bacteria may cause the flavor.

\section{NATURE OF MEDIUM HAVING METALLIC FLAVOR IN THE GREATEST DEGREE}

The senses of taste and smell are the only means by which metallic flavor can be detected, and it is to be expected that the nature of the medium will influence these senses. It has already been stated that a high proportion of butterfat seems necessary for the production of metallic flavor, except in the case of buttermilk. Cream often showed only a trace of the flavor, but the flavor of buttermilk from the same cream churned in a glass bottle was very metallic. This showed that either the serum was more easily tasted than was the cream because of its physical nature, or else it was more metallic in flavor. The former is probably true, and the latter, according to work done and recorded later in this bulletin, is also true.

A few experiments were made in separating the water and the solids in buttermilk by centrifugal force. Buttermilk was put into a glass tube and placed in a centrifuge. After separation, the water and the solids were carefully examined in order to determine which had the more metallic flavor. No difference was noticed.

The metallic flavor appears to be volatile. In buttermilk that had developed the flavor in a glass bottle, the metallic odor was very noticeable immediately after the removal of the stopper. Several attempts were made to concentrate the flavor. Portions of the metallic buttermilk were distilled, and the distillate was then condensed by evaporation, but no metallic flavor was apparent. Instead the flavor was flat and oily.

It is difficult to explain why metallic flavor develops to a greater degree in buttermilk than in any other dairy product. As has already been stated, a high proportion of butterfat is generally essential for the production of metallic flavor, and ordinarily it does not develop in serum 
alone, such as skimmed milk; but in buttermilk, which contains only a little more fat than does skimmer milk, the flavor becomes very pronounced. It was thought that there might be a relation between the acids of the butterfat and the metallic flavor. For example, some of these volatile acids might be in buttermilk and not in skimmed milk. Samples of butyric, caproic, caprylic, palmitic, stearic, and olcic acids were obtained, also propionic acid, which is lower in the fatty acid series, and succinic acid, which is a dibasic organic acid and may be found in dairy products. No sign of metallic flavor, however, could be detected in any of these acids.

\section{FACTORS AFFECTING DEVELOPMENT OF METALLIC FLAVOR}

\section{RELATION OF FAT CONTENT TO METALLIC FLAVOR}

Twenty-six samples of skimmed milk were placed in sterilized glass bottles and inoculated with buttermilk having metallic flavor. Only two of the samples showed any indication of metallic flavor, and in these the flavor could hardly be called metallic.

Forty-three samples of whole milk were treated in like manner. Only four developed metallic flavor, and in these the flavor was noticeable only in the cream on the surface.

Sixty-six samples of cream were inoculated with buttermilk having metallic flavor, and held in sterilized glass bottles. Seventeen of the sixtysix samples developed metallic flavor, a few of these being strongly metallic. In addition to the sixty-six samples, five samples of cream were allowed to stand at room temperature without inoculation. Four of these developed metallic flavor. The five samples were obtained from a source in which metallic flavor had previously appeared.

It has already been stated that metallic flavor has not been observed in cottage cheese, but that it is often very strong in soft cream cheese. It therefore seems apparent that the presence of fat in fairly large quantities is necessary for the flavor to develop.

\section{RELATION OF ACIDITY TO METALLIC FLAVOR}

Samples of buttermilk were placed in sterilized glass bottles and metallic flavor was allowed to develop. Of sixty-nine samples the acidity was noted in nineteen, and of these nineteen samples the acidity of six samples was taken both before and after the flavor became metallic. The results are shown in table.$^{2}$ The acidity of all the nineteen samples after metallic flavor developed varied from 0.69 to $0.8_{3}$ per cent.

In many other samples of which no record was kept, it was possible to detect metallic flavor when the buttermilk became highly acid, and not until then.

\footnotetext{
${ }_{2}^{2}$ Tables referred to in this bulletin are printed in the appendix, pages 629 to 643 .
} 


\section{TEMPERATURE IN RELATION TO METALLIC FLAVOR}

It was thought that metallic flavor developed more rapidly at low temperatures - as, for example, in the refrigerator - than at room temperature. A series of experiments was conducted in order to determine this question. The results are given in table 2 (page 629).

The effects of different temperatures on the flavor varied but little. It is interesting to note, however, that some of the room-temperature samples showed a more pronounced metallic flavor than was found at the low temperatures, although probably the average of the low-temperature samples had a stronger flavor than the average of the room-temperature samples.

It is probable that other flavors develop at higher temperatures, which have a tendency to hide metallic flavor if it is present. However, if the product is tasted at the proper time, there is no doubt that metallic flavor will be found in no uncertain degree.

\section{EFFECT OF COOKED FLAVOR IN RELATION TO METALLIC FLAVOR}

As already noted (page $6 \mathrm{II}$ ), there is a difference of opinion regarding the effect of pasteurization on development of metallic flavor. In the course of this study several attempts were made to produce the flavor in pasteurized or sterilized cream, but since the cooked flavor masked most of the other flavors it was very difficult to reach any definite conclusion. One hundred and sixty-three attempts were made to produce metallic flavor in either sterilized or pastcurized cream, by inoculation with metallic-flavored buttermilk. In only two of the samples was the metallic flavor distinguished from the cooked flavor.

\section{METHOD OF OBTAINING A MEDIUM FOR DETECTION OF METALLIC FLAVOR}

In order to obtain a medium for detecting metallic flavor in dairy products, the common method of sterilization of cream by heat was first tried. Cream having a butterfat content of about 30 per cent was sterilized in the steam bath on three consecutive days, but the cooked flavor so masked the other flavors that this method could not be used. Lower temperatures were then tried. About 20 cubic centimeters of cream having a butterfat content of 30 per cent was put into test tubes. The wire container, with the tubes, was placed in water, and the temperature was raised to $140^{\circ} \mathrm{F}$. and maintained at that point for twenty minutes. The process was repeated on three consecutive days. One hundred and three test tubes of this sterilized cream were then inoculated with metallicflavored buttermilk; only two showed metallic flavor. In many cases the judges thought they could detect a slight metallic flavor or one similar 
to it, but they were not certain, for the cooked flavor was present to a considerable degree.

Germicides were next considered, but nothing tasteless could be found. It was thought that volatile antiseptics might be used, such as ether or chloroform. Heat could then be applied to eliminate the antiseptics, but the physical properties of the cream were changed, this assuming a greasy appearance and an oily taste.

The only alternative seemed to be raw cream, and therefore milk was obtained directly from the cow. At first it was milked into large sterilized glass bottles and allowed to stand for twenty-four hours. At the end of that time the serum in the bottom of the bottles was drawn off with a sterilized pipette. Several trials were run, the cream being divided into portions of 50 cubic centimeters and put into smaller sterilized glass bottles. Each portion was inoculated with from one-half to one cubic centimeter of metallic-flavored buttermilk. Of twenty-three samples of this cream, eight developed metallic flavor.

Two objections to this method of separation became apparent. First, the cream was not sufficiently rich in butterfat, for it is not possible to obtain cream with a high fat content when the separation is done by any of the gravity methods. This high fat content is one of the essential conditions for the devclopment of metallic flavor. Secondly, too much bacterial growth took place during the creaming process, which made the cream an uncertain medium for the study of the organisms that produce metallic flavor.

An attempt was next made to use cream from the market milk laboratory. This cream was standardized to a fat content of 32 per cent, and from this standpoint it was ideal. One hundred and seven samples of this cream were put into sterilized glass bottles. Each sample consisted of about 50 cubic centimeters of cream and was inoculated with from one-half to one cubic centimeter of metallic-flavored buttermilk. Thirtynine of the samples showed metallic flavor. Two sets, of six samples each, were carefully tasted immediately after inoculation. Not a trace of metallic flavor could be detected. As additional evidence that this cream was not affected by contact with tin, it should be noted that not a check sample showed metallic flavor.

There was one factor in connection with the cream from the market milk laboratory that made it unsatisfactory: it contained a number of microorganisms which made interpretation of the results difficult. When metallic flavor was found in these samples, the question could well be asked, Was the flavor produced by organisms in the metallic-flavored buttermilk with which the cream was inoculated, or was there an associative action between the organisms in the buttermilk and those already in the cream? 
In the search for better cream it was learned that the milk from a certain cow in the university herd usually showed the low bacteria count of from two to three hundred per cubic centimeter. In fact, the analysis of one milking showed only six bacteria per cubic centimeter. It was possible to hold the cream from this cow for about forty-eight hours at room temperature without much change. It therefore seemed that the associative action of the bacteria in the metallic-flavored buttermilk and in this cream would be almost negative. Therefore the remainder of the cream medium was obtained by taking milk from this cow, milking into a sterilized covered pail. The milk was taken immediately to the laboratory and separated in a sterilized separator, the cream being caught in sterilized glass bottles. As soon as the separation was complete, the cream was divided into portions of 50 cubic centimeters in sterilized glass bottles, and immediately inoculated.

\section{BACTERIA IN SOME METALLIC-FLAVORED DAIRY PRODUCTS}

The first series of samples to be examined for bacteria consisted of metallic-flavored butter. Five samples were plated in lactose agar and a brief morphological and cultural study was made, with the following results:

Sample I. On one plate of the first sample there were twenty brown colonies in tetrads, and several milky white colonies. These organisms were micrococci. A few small acid colonies and one of Oidium lactis were found.

Sample 2. The second sample contained several spreaders, and one milky white colony with a regular edge which was a streptococcus. There were two chalky white colonies with very irregular edges and a wrinkled surface. These organisms were short, rod-shaped, and with rounded ends, and were nonmotile. Several small cream-colored punctiform colonies were present, which under the microscope appeared very much like Oidium lactis but were much smaller. Seventy-five Oidium lactis organisms were found.

Sample 3. In the third sample eight cream-colored colonies were found which were diplococci. There were two small brown colonies of staphylococci, and a few milky white colonies of bacteria which were nonmotile, short, and rod-shaped, with rounded ends.

Sample 4. In the fourth sample there were several small punctiform cream-colored colonies, three milky white colonies which were micrococci, and thirty colonies of Oidium lactis.

Sample 5. The one plate of the fifth sample that could be used contained only seven colonies. All were white and spreading, and the organisms were nonmotile, short, and rod-shaped.

No one organism was present in all the five samples. The organism that 
was most abundant was Oidium lactis, but this was found in only three of the samples. To determine the effect of Oidium lactis in cream, six samples were inoculated with this organism; none of these developed metallic flavor.

Since it was possible to obtain metallic flavor almost at will in the buttermilk of the university laboratory, a study was made of the milk and cream delivered at one of the six receiving stations. A sample of each patron's milk or cream was put into a sterilized glass bottle. Room temperatures were used for incubation. The results are given in table 3 (page 630). It is seen from the table that two samples, one of cream (no. 2 I) and one of whole milk (no. 62), had metallic flavor. The flavor was stronger in the cream sample, and this was plated in order to determine whether or not the organism Oidium lactis was present - the idea having been suggested by Bouska (page 609) that Oidium lactis might be the cause of metallic flavor. A large number of colonies of Oidium lactis were found.

The results of a second study of the milk and cream at the same station are given in table 4 (page 63I). Again sample 2I had metallic flavor, but sample 62 showed no trace of it. Another cream sample, however, no. 25, was metallic in flavor.

The impression is somewhat prevalent that cream of a high grade does not develop metallic flavor. It should be noted that in both studies sample 2I when fresh was judged as good. On the other hand, sample 62 was only fair in flavor when fresh, and soon turned to bad. Later four samples of cream, all of good flavor, were taken on different days from the patron who supplied sample 2I. All these samples developed metallic flavor. It therefore seems that the flavor may develop in either good or poor cream.

In the experiment reported in table 4 , an examination was made of all the samples for the presence of Oidium lactis. It is seen in the table that twenty of the thirty-two samples contained this organism. It should be noted, however, that the two samples which were metallic in flavor contained no Oidium lactis.

\section{FORMALDEHYDE AND METALLIC FLAVOR}

Formaldehyde is considered a very efficacious disinfectant. It kills not only bacteria, but also their enzymes. A study was made of the effect of formaldehyde on the development of metallic flavor in buttermilk. Samples of buttermilk that was not metallic in flavor were taken fresh from the churn and immediately treated with formalin (a solution containing from 37 to 40 per cent of formaldehyde). The results are shown in table 5 (page 632 ). It is seen from the table that in only a small proportion of the samples did metallic flavor not develop. Of the fortyone samples treated, thirty-five were metallic in flavor. 
In order to determine the efficiency of the formalin a bacteriological examination was made, with rather surprising results. All the samples were incubated at room temperature for two days. On some of the plates there were many organisms. The results are shown in table 6 (page 633). These results indicate that formalin does not kill all the bacteria in buttermilk; it does, however, undoubtedly retard their growth.

\section{EFFECT OF ADDING PURE LACTIC ACID TO SOME DAIRY PRODUCTS}

Inasmuch as metallic flavor was developed in sterilized glass bottles in the presence of formalin, a substance that either kills or checks the growth of microorganisms and possibly checks enzymic growth, the question arose, What would be the effect of adding pure lactic acid to fresh buttermilk that is not metallic in flavor, or to skimmed milk? The reason for such a question was that a flavor of metallic nature might be produced by the action of the lactic acid and the serum of the buttermilk under certain conditions. Several experiments were run with varying quantities of pure lactic acid, but there was no trace of metallic flavor.

\section{RELATION OF ENZYMIC GROWTH TO METALLIC FLAVOR}

A limited study was made of the relation of enzymic growth to metallic flavor. The first problem in this connection was to find a solution that would effectually check the growth of the microorganisms and yet permit the enzymes to grow, and would not impart to the medium a flavor that would make detection of the metallic flavor difficult or impossible. No solution was found that left the metallic flavor clear and distinct. One compound, however, could be so managed as to make possible the detection of metallic flavor in at least a small number of samples.

Three per cent by measure of toluene was first used in buttermilk. Toluene is considered one of the most effective substances to check the growth of bacteria and still permit enzymic action, but the flavor is so sharp that detection of other flavors is impossible. The toluene could not be removed by heat, for its boiling point is $110^{\circ} \mathrm{C}$. and if such a temperature were used the buttermilk would be scorched. Four unsuccessful attempts in the use of toluene were made.

The next agent to be tried was chloroform, which has a boiling point of $6 \mathrm{r} .2^{\circ} \mathrm{C}$. and can therefore be readily evaporated at a temperature that does not affect the flavor of buttermilk. According to Harding and Van Slyke (1907); 2.5 per cent of chloroform will check the growth of any microorganism in milk and not retard enzymic growth. In the experiments with chloroform, 50 cubic centimeters of fresh buttermilk, 
not metallic in flavor, was placed in each of two sterilized glass bottles. One of these bottles was held as a check. In the other, 2.5 per cent by measure of chloroform was added. The mixture was then thoroughly shaken and kept at room temperature. The chloroform had a tendency to settle to the bottom; consequently it was necessary to shake the mixture several times in a day. At the end of two days about 20 cubic centimeters of the chloroformed buttermilk was put into a beaker and placed in water over a bunsen burner. The temperature of the water was maintained at from $62^{\circ}$ to $65^{\circ} \mathrm{C}$. until all the chloroform was evaporated. This process required about twenty minutes. Fourteen trials were made, in two of which a slight metallic flavor seemed to have developed. A sweetish flavor, resulting from the chloroform, always remained. In every case the check sample became metallic in flavor.

This study was not satisfactory, largely because of the difficulty in distinguishing the flavors after the buttermilk had been treated. Nevertheless, the indications were that metallic flavor might be produced by enzymic action.

\section{NUMBER OF BACTERIA IN BUTTERMILK BEFORE AND AFTER DEVELOPMENT OF METALLIC FLAVOR}

It was thought best, among other things, to determine the number of bacteria in the buttermilk before and after development of metallic flavor, for there were strong indications that the flavor might be caused by bacteria. Lactose agar and lactose gelatin were the media used. As has already been stated, high acidity seemed essential in the development of the flavor, and therefore media of different acid content were used. The regular lactose agar and lactose gelatin were prepared with an acidity of $+\mathbf{I} .5$ (equivalent to 0.135 per cent lactic acid, which is a little lower than the acidity of sweet milk), and the other agar and gelatin were prepared with from 0.75 to 0.8 per cent of lactic acid (which is about the same as the acidity of the buttermilk that showed the strongest metallic flavor).

Much difficulty was experienced in preparing the agar and the gelatin with the high acidity of from 0.75 to 0.8 per cent. At first the acid was added in the same manner as in making the regular medium, but when the agar was sterilized it would not congeal. After several unsuccessful attempts the writer learned from Bouska (page 609) that the addition of tartaric acid before sterilization prevents solidification of the agar, but if the acid is added after sterilization it does not have this effect. This method was tried with the lactic acid, with satisfactory results.

The question of sterilization of the lactic acid solution was next considered, but on bacterial analysis it was found that the solution was already 
sterile. The strength of this solution was nine-tenths of normal. When one cubic centimeter was placed in ten cubic centimeters of the agar or the gelatin, the percentage of lactic acid was from 0.75 to 0.8 per cent, depending on the age of the medium and therefore on the amount of evaporation that had taken place - it having been held for a part of the time at room temperature.

A study of table 7 (page 634), showing the number of bacteria in the buttermilk before and after metallic flavor developed, shows certain facts. First, there is no direct relationship between the number of bacteria and the metallic flavor, for in sample I only about 5,000,000 bacteria were found in the metallic-flavored buttermilk as against over 328,000,000 in sample r3. Secondly, there may be an increase or a decrease in the number of bacteria from the fresh to the metallic-flavored stage of the buttermilk; six samples show an increase and ten a decrease when grown on plain lactose agar, while in the high-acid agar three samples decreased in number of bacteria and eight increased. Thirdly, only a small proportion of the bacteria that grow in the lactose media with an acidity of $+\mathrm{I} .5$ will grow on the lactose media with from 0.75 to 0.8 per cent of lactic acid.

It is seen in table 7 that cleven samples of buttermilk were plated on both agars at room temperature before and after the buttermilk became metallic in flavor. The ratios of the numbers of bacteria in these eleven samples in the two agars are shown in table 8 (page 635). Even though these ratios show a greater proportion of bacteria growing on the highacid agar in the metallic-flavored buttermilk than in the fresh buttermilk, this does not scem particularly significant, for table 8 shows that there was great variation. Further, one would naturally expect to find a greater proportion of the bacteria producing metallic flavor growing on the highacid medium, for metallic-flavored buttermilk, as already stated, is always high in lactic acid, and this of itself would tend to eliminate other bacteria that could not exist in a high-acid medium.

\section{A QUALITATIVE STUDY OF THE BACTERIA IN FRESH AND IN METALLIC-FLAVORED BUTTERMILK}

At the same time that the bacteria in the fresh and the metallic-flavored buttermilk were counted, a study was made of their action on litmus milk, which was prepared in the following manner: A litmus solution with an acidity of +1.5 was added to fresh skimmed milk at the rate of I. 5 cubic centimeters of litmus solution to ro cubic centimeters of skimmed milk. After being thoroughly mixed, the litmus milk was put into sterilized test tubes, about io cubic centimeters in each tube. It was then 
sterilized in the steam bath, by the intermittent method, on three consecutive days. The tubes were kept in the bath for thirty minutes each day.

The litmus milk was inoculated from the plates from which the counts were obtained as recorded in table 7 . The inoculation consisted in transferring a part or the whole of an individual colony to a single tube of milk, the transfer being made with the end of a platinum needle pounded flat and bent in the form of a short hook. The number of tubes inoculated from one plate varied from io to 146 , as seen in tables 9 and io (pages $6{ }_{3} 6$ and 637 ). The tubes were held at room temperature, and records were taken on the second, fifth, and fourteenth days after inoculation. The classes recorded were acid producing, acid producing with coagulation, peptonizers, alkaline, and inert.

If the group classed as peptonizers had appeared in larger numbers, it would have been necessary to hold the tubes longer than two weeks in order to give sufficient time for the peptonization process. But because of the probability that this group, which was very small, did not cause metallic flavor, the final record was taken on the fourteenth day.

The results of the study of the organisms transferred from agar of the lower acidity are shown in table 9 (page 636). The table shows that on the fourteenth day the average percentage of bacteria that produced acid and caused coagulation was 72.95 . In the inert class there was an average percentage of 18.58 , and in the group that showed acid production only there was an average percentage of 7.29 .

Very different results appear in table ro (page 637), which shows the bacterial action when a high-acid medium is used. The group showing acid production alone was much larger than for the normal medium, but in only one sample was there any coagulation, demonstrating that the bacteria which cause coagulation do not grow in a high-acid medium.

It is noticeable that the percentages of bacteria in all the groups as shown in both tables vary considerably. It is possible that in the case of the inert group some of the tubes were not inoculated. With the normal medium, however (table 9), the percentage of the inert group was small with the exception of two samples, leading to the conclusion that the number of unsuccessful transfers was small. Granting that all the tubes were properly inoculated, it is seen that in the high-acid agar on the fourteenth day an average of 56.79 per cent of the bacteria had not grown in litmus milk, while in the acid-producing group there was an average percentage of 38.9 .3 .

Because of the fact that metallic flavor was found only in dairy products of high acid content, it was natural to first study the group of bacteria that grew well on the high-acid medium and the group that would produce 
acid. One set of twenty samples of cream was inoculated. The cream was examined when ripe, and the flavor was pronounced bitter. It did not resemble metallic flavor in the slightest degree.

The next bacteria to be studied were those of the group producing acid with coagulation. Twenty tubes were taken at random from about two hundred containing these bacteria. Samples of cream, each consisting of 20 cubic centimeters, were inoculated respectively with $\frac{1}{2}$ cubic centimeter or less of the milk coagulum from each of the tubes. The samples of inoculated cream were held for thirty-six hours at room temperature, and were then placed in the refrigerator for another thirty-six hours before being judged. ${ }^{3}$

In the first trial of this experiment (table I , page 638 ), three or more of the five judges pronounced thirteen of the twenty samples metallic in flavor. In the second trial (table 12 , page $6{ }_{3} 8$ ), only two of the twenty samples were pronounced metallic in flavor by two of the three judges. In the third trial (table I3, page 639), three of the twenty samples were pronounced metallic in flavor by three of the four judges.

These results were not satisfactory, for there was considerable difference of opinion. In many cases there was a flavor which was somewhat similar to metallic flavor and yet could not be termed metallic. Some of the samples had seemingly passed through the metallic-flavored stage, and other flavors had developed which masked the metallic flavor.

Because of the difficulty in detecting the flavor, another trial was made. This time about I 50 cubic centimeters of cream was used. All the samples were inoculated and ripened in the same manner as in the preceding trials. They were then churned by hand in the sample bottle in which the cream was ripened.

Eighteen of these twenty samples (table I4, page 639) were pronounced metallic in flavor by three or more of the five judges. The remaining two samples seemed to have the flavor to a very slight degree, but it was not sufficiently strong to warrant judging the samples as metallic-flavored. It should be noted, however, that sample 5 was in the first trial pronounced metallic in flavor by three of the five judges; and in the case of sample 7 , in the first and fourth trials one judge pronounced the flavor metallic and another considered it doubtful, in the second trial the sample was pronounced metallic in flavor by the judge who raised a question about it in the first trial, and in the third trial two of the four judges placed it with the metallic-flavored samples. It would therefore seem that these samples also probably had metallic flavor in a slight degree.

${ }^{3}$ The judges were: H. L. Ayres, extension instructor, and instructor in butter making in the winter course, at Cornell University; H. W. Middaugh, superintendent of milk supply, formerly head butter maker; W. A. Luce, head butter maker; H. M. Pickerill, instructor in bacteriology, formerly assistant in the butter laboratory; and the writer. 
A year after this work was done, a sample of buttermilk was obtained from the creamery laboratory and a study of the bacteria contained in it was made in the same manner as were the previous studies. Samples of cream were also obtained, in the manner described on page 6r9. About I 50 cubic centimeters of cream was inoculated from a tube of the bacteria producing acid with coagulation. The cream was churned when ripe, and the flavor of the resulting buttermilk was studied. ${ }^{4}$

The results of the experiment (tal)le 15, page 640) were peculiar and uncertain. In the first place, the check sample was pronounced metallic in flavor by all the five judges, winile four of the sixteen inoculated samples showed no trace of metallic flavor. It must be remembered that the check sample was not sterile and could not be made sterile without affecting the flavor of the cream. Under such conditions it is to be expected that a check sample would occasionally show metallic flavor.

Another experiment was made with thirteen inoculated samples. ${ }^{5}$ In this experiment the check sample was not metallic in flavor. Three of the inoculated samples (table $I 6$, page $6+1$ ) were pronounced metallic in flavor by four or more of the eight judges. With three exceptions, all the other samples were classed as metallic-flavored by at least one of the eight judges, and in the case of one of the exceptional samples four of the judges raised the question as to whether or not the flavor was metallic.

\section{MORPHOLOGICAL CHARACTERISTICS}

The bacteria in each culture were carefully studicd under the microscope. They were found to be nonmotile, very short, and rod-shaped, appearing singly and in chains of two or more. A few of the chains contained seven or eight bacteria. They appeared to be the same as the wellknown bacteria found in milk - the Bacterium lactis acidi group; if there was any difference it was in size, these appearing to be a little larger than those representative of the group, but the difference was slight.

\section{CULTURAL CHARACTERISTICS}

In all the tubes of litmus milk coagulation took place, and all samples showed growth without liquefaction on gelatin. These are the two cultural characters that have generally been used to identify members of the Bacterium lactis acidi group.

Further study of cultural characteristics seemed necessary. It has been usually considered that certain zymogenic bacteria can be more easily recognized by their growth on the various sugars and closely related sub-

\footnotetext{
1 The judges were the same as in the earlier work, with the addition of Professor N. W. Hepburn, of the University of Illinois.

5 Additional judges in this experiment were G. C. Supplee, assistant in the butter laboratory; and V. R. Jones, assistant in the testing laboratory.
} 
stances than on any other media. Consequently a study was made of the bacteria on lactose, dextrose, saccharose, and raffinose, on the polysaccharide inulin, and on the alcohols mannite and glycerin. The nutrient solutions were prepared as by Rogers and Davis (I9I2), with the following proportions:

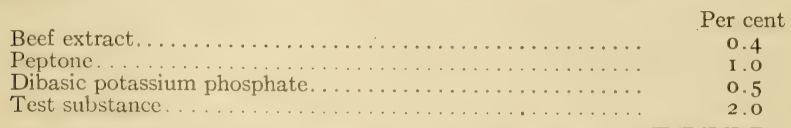

In these experiments the age of the bacteria was not constant at the time of inoculation, for according to Rogers and Davis (I9I2) this is not necessary. They say (page 20 of reference cited): "In our own work no systematic investigation was undertaken to determine the constancy of the fermentation reactions, but all our observations tend to prove that the property of forming acid from carbohydrates and similar substances is not easily lost or acquired. One culture showing no evidence of ability to ferment saccharose was carried for one hundred generations, or a period of about one year, on a saccharose-agar. At the end of this period the culture still showed no fermentation of saccharose and the lactose fermentation remained unchanged."

Rogers and Davis consider that acid formation is the most important factor to be observed in the study of lactic acid bacteria. In these studies, however, the writer observed, along with the acid development, the appearance of the media and whether or not gas was produced.

The inverted-inner-tube method was used for the detection of gas. The cultures were incubated at room temperature for seven days. The acidity of the media was +r.5. The titration was made in duplicate with $\mathrm{N} / 20 \mathrm{NaOH}$ solution. The results of two studies of these bacteria when grown in the above solutions are given in tables I 7 and I 8 (pages 642 and 643 ). The percentage of samples that showed growth in the two tests are summarized in table I9 (page 643). These figures are very much like those reported by Rogers and Davis (I9I2), which they have assigned to the class generally known as the Bacterium lactis acidi group.

Further study should be made in order to determine the strain of the Bacterium lactis acidi group to which these organisms belong. A few attempts have been made to study the various strains of this group, but thus far very little has been accomplished.

\section{CONCLUSIONS}

Direct absorption of metals may cause metallic flavor in dairy products. Bacteria may cause metallic flavor. Buttermilk in sterilized glass bottles developed the flavor in many cases. Of $24 \mathrm{I}$ samples of cream in 
sterilized glass bottles, metallic flavor was produced in 79 by inoculation with metallic-flavored buttermilk; and of 157 samples of cream in sterjlized glass bottles, which were inoculated with individual bacteria, 52 showed metallic flavor.

The organism that causes metallic flavor is a member or a strain of the Bacterium lactis acidi group.

Except in the case of buttermilk, a high fat content of the medium is essential for the production of metallic flavor.

Metallic flavor may develop in cream of either good or poor flavor.

The indications are that enzymes may be a factor in the production of metallic flavor.

High acidity of the medium is a necessary condition for development of metallic flavor.

\section{BIBLIOGRAPHY}

\section{Brown, Leroy A.}

I9I2 Metallic flavor. New York prod. rev. and Amer. creamery $35: 226$.

Golding, John, and Feilmann, Ernest

I905 Taint in milk due to contamination by copper. Soc. Chem. Indus. Journ. 24: $1285^{-I} 286$.

Harding, H. A., and Van Slyke, L. L.

1907 Chloroform as an aid in the study of milk enzyms. New York (Geneva) Agr. Exp. Sta. Tech. bul. 6:4I-82.

\section{Irish Homestead}

I9I3 A metallic flavor. In Chicago dairy produce I9:45: I3.

Melick, C. K.

I9I2 Metallic flavor theories. New York prod. rev. and Amer. creamery $35: 430$.

New York Produce Review and American Creamery

I9I2 Metallic flavor. New York prod. rev. and Amer. creamery $35: 227$.

Rogers, L. A., Berg, W. N., Potteiger, C. R., and Davis, B. J.

I9I3 Factors influencing the change in flavor in storage butter. U. S. Anim. Indus. Bur. Bul. I62:5-69.

Rogers, L. A., and Davis, B. J.

I9I2 Methods of classifying the lactic-acid bacteria. U. S. Anim. Indus. Bur. Bul. I54:7-30. 


\section{APPENDIX}

TABle i. Acidity of Buttermilk Before and After Development of Metallic Flavor

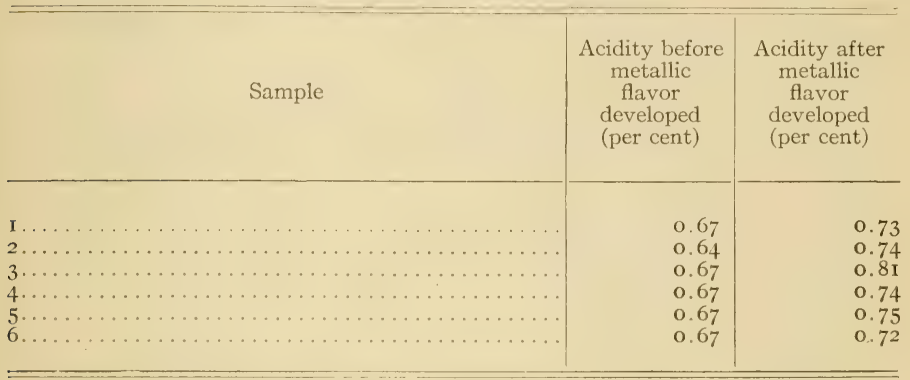

Table 2. Effect of Temperature on Development of Metallic Flavor

\begin{tabular}{|c|c|c|c|}
\hline Experiment & $\begin{array}{l}\text { Number of } \\
\text { samples } \\
\text { metallic in } \\
\text { flavor at } \\
\text { low tem- } \\
\text { perature }\end{array}$ & $\begin{array}{l}\text { Number of } \\
\text { samples } \\
\text { metallic in } \\
\text { flavor at } \\
\text { room tem- } \\
\text { perature }\end{array}$ & Remarks \\
\hline I $\ldots \ldots \ldots$ & I & I & $\begin{array}{l}\text { Low-temperature sample more metallic in } \\
\text { flavor than room-temperature sample }\end{array}$ \\
\hline $2 \ldots$ & I & I & $\begin{array}{l}\text { Low-temperature sample more metallic in } \\
\text { flavor than room-temperature sample }\end{array}$ \\
\hline $3 \ldots$. & I & I & $\begin{array}{l}\text { Low-temperature sample more metallic in } \\
\text { flavor than room-temperature sample }\end{array}$ \\
\hline $4 \cdot \therefore \ldots \ldots$ & I & I & $\begin{array}{l}\text { Low-temperature sample more metallic in } \\
\text { flavor than room-temperature sample }\end{array}$ \\
\hline $5 \ldots \ldots \ldots$ & I & I & $\begin{array}{l}\text { Low-temperature sample more metallic in } \\
\text { flavor than room-temperature sample }\end{array}$ \\
\hline 6. . & I & I & $\begin{array}{l}\text { Room-temperature sample more metallic } \\
\text { in flavor than low-temperature sample }\end{array}$ \\
\hline & I & I & $\begin{array}{l}\text { Room-temperature sample more metallic } \\
\text { in flavor than low-temperature sample }\end{array}$ \\
\hline & o & 6 & $\begin{array}{l}\text { None of the six were metallic at low- } \\
\text { temperature }\end{array}$ \\
\hline 9. & 4 & 3 & $\begin{array}{l}\text { Room-temperature sample more metallic } \\
\text { in flavor than low-temperature sample }\end{array}$ \\
\hline
\end{tabular}




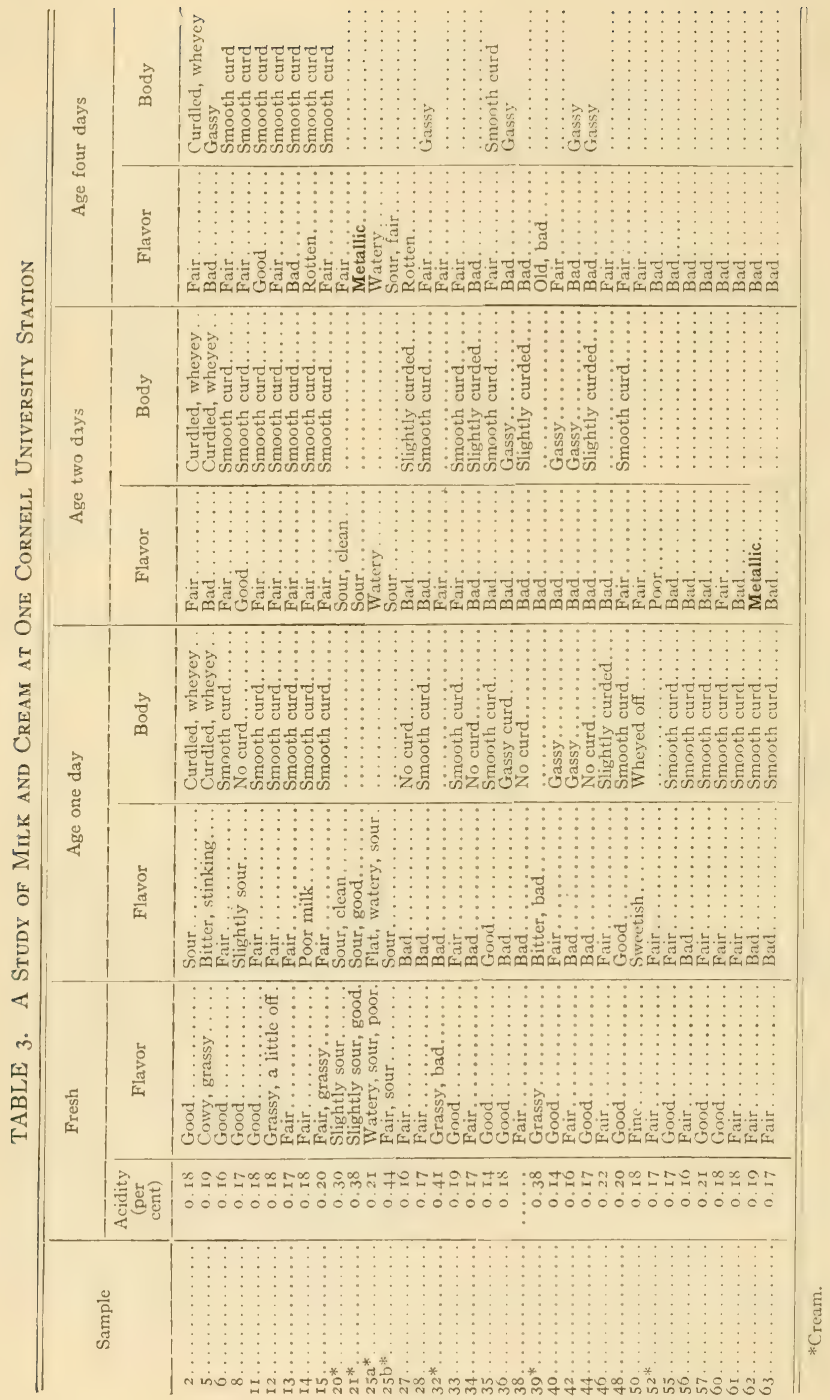


TABle 4. A Study of MilK and Cream at One Cornell University Station

\begin{tabular}{|c|c|c|c|}
\hline \multirow{2}{*}{ Sample } & \multicolumn{2}{|c|}{ Flavor } & \multirow{2}{*}{$\begin{array}{l}\text { Oidium } \\
\text { lactis }\end{array}$} \\
\hline & When fresh & When one day old & \\
\hline & Good & 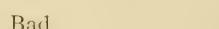 & \\
\hline $6 \ldots \ldots \ldots$ & Gond ........ & $\begin{array}{l}\text { Bad. . . . . . . . } \\
\text { Fair. . }\end{array}$ & 二 \\
\hline $7 \ldots \ldots \ldots$ & Fair. & Bad........... & $\bar{t}$ \\
\hline $8 \ldots \ldots$ & Good. . & Fair... & + \\
\hline II $\ldots \ldots \ldots \ldots$ & Good .......... & Fair. . . . . . & \pm \\
\hline $12 \ldots \ldots \ldots \ldots$ & Good.......... & 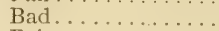 & + \\
\hline I $3 \ldots \ldots \ldots \ldots$ & Good......... & Fair. . . . . . . . & + \\
\hline $14 \ldots \ldots \ldots \ldots$ & Good ........... & Fair... & + \\
\hline I6. & Good. & Bad.......... & - \\
\hline $21^{*}$. & Good. & Slightly metallic.... & - \\
\hline $25^{*}$. & Fair.......... & Slightly metallic.... & - \\
\hline $27 \ldots \ldots \ldots \ldots \ldots$ & Fair.......... & 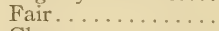 & + \\
\hline $28 \ldots$ & Good. . & Cheesy........... & + \\
\hline $32 *$ & Fair. . & Fair . . . . . . . & + \\
\hline $33 \ldots$ & Goorl. & Bad .......... & + \\
\hline 36 . & Bad.. & Cheesy........... & + \\
\hline $39^{*}$. & Bad.. & 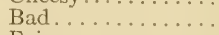 & + \\
\hline $40 \ldots \ldots \ldots \ldots$ & Fair. . & Fair. . . . . . . . & - \\
\hline $42 \ldots \ldots \ldots \ldots \ldots$ & Good. . & Bad.............. & + \\
\hline 44. & Fair. & Fair.............. & - \\
\hline 46. & Fair. & Good ........... & + \\
\hline $48 \ldots$ & Fair. & Fair........... & + \\
\hline 49. & Fair. & Fair . . . . . . . & + \\
\hline & Fair.. & Rotten........... . & - \\
\hline $52^{*}$. & Good. . & Fair........... & 一 \\
\hline $55 \ldots \ldots \ldots \ldots$ & Good .......... & Fair............ & + \\
\hline $5^{6} \ldots \ldots \ldots \ldots \ldots$ & Fair .......... & Bad............. & - \\
\hline $57 \ldots \ldots \ldots \ldots$ & Fair... & Fair ............ & - \\
\hline $60 \ldots \ldots \ldots \ldots$ & Good . . . . . . . & Good........... & + \\
\hline $6 \mathrm{r} \ldots \ldots \ldots \ldots \ldots$ & Good......... & Good............ & + \\
\hline $62 \ldots \ldots \ldots \ldots \ldots$ & Fair. . & Fair . . . . . . . & + \\
\hline $63 \ldots \ldots \ldots$ & Good.......... & Bad............ & + \\
\hline
\end{tabular}

* Cream. 
Table 5. Effect of Formaldehyde on Metallic Flavor in Buttermilk

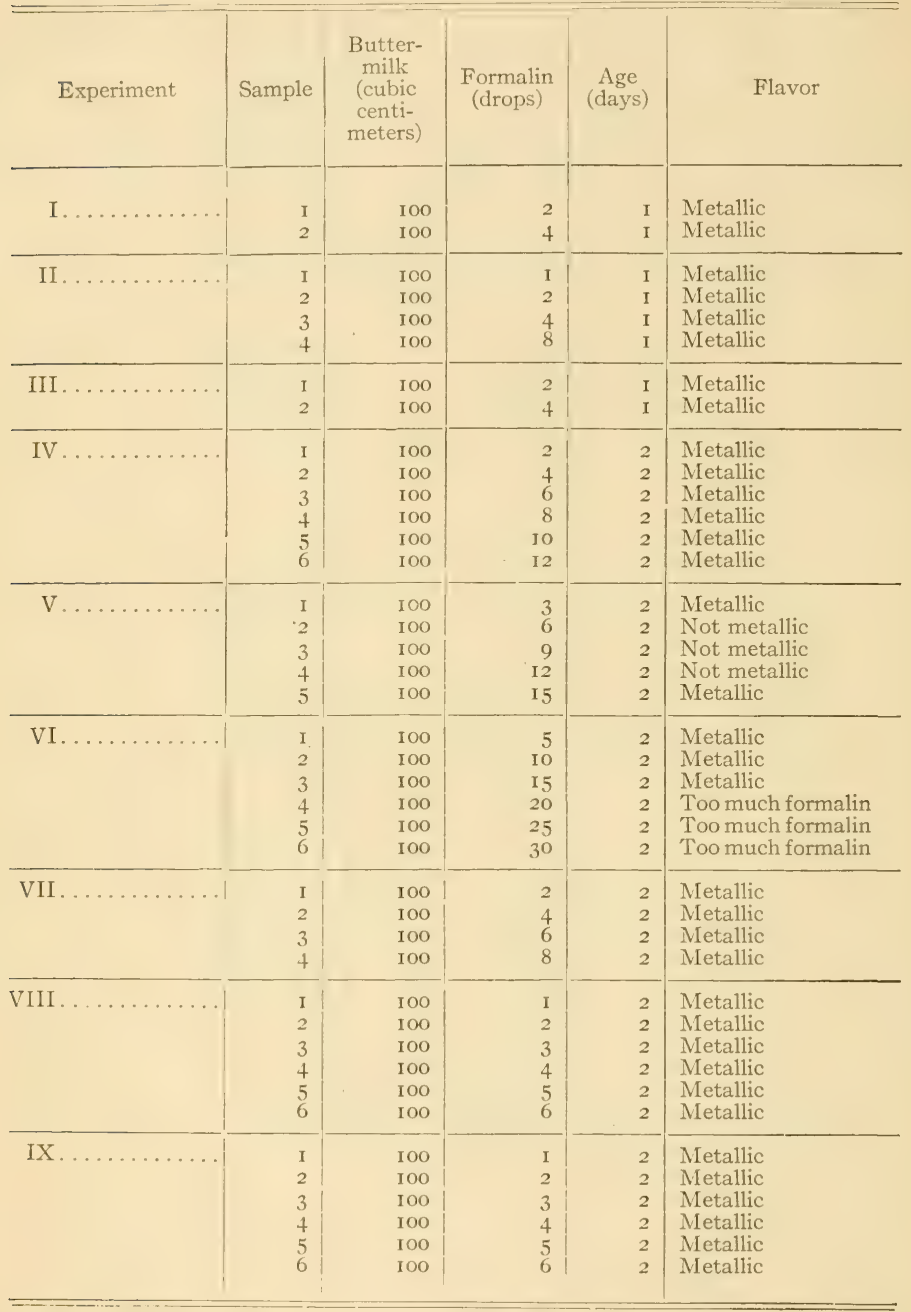


TABLE 6. EFFEct OF Formaldehyde on BACteria in ButTermilk

\begin{tabular}{|c|c|c|c|c|c|}
\hline Experiment & Sample & $\begin{array}{l}\text { Butter- } \\
\text { milk } \\
\text { (cubic } \\
\text { centi- } \\
\text { meters) }\end{array}$ & $\begin{array}{l}\text { Formalin } \\
\text { (drops) }\end{array}$ & $\begin{array}{c}\text { Bacteria } \\
\text { per } \\
\text { loop }\end{array}$ & Flavor \\
\hline V. & $\begin{array}{l}1 \\
2 \\
3 \\
4 \\
5\end{array}$ & $\begin{array}{l}100 \\
100 \\
100 \\
100 \\
100\end{array}$ & $\begin{array}{r}3 \\
6 \\
9 \\
12 \\
15\end{array}$ & $\begin{array}{l}90 \\
60 \\
20 \\
15 \\
18\end{array}$ & $\begin{array}{l}\text { Metallic } \\
\text { Not metallic } \\
\text { Not metallic } \\
\text { Not metallic } \\
\text { Metallic }\end{array}$ \\
\hline VI....... & $\begin{array}{l}1 \\
2 \\
3 \\
4 \\
5 \\
6\end{array}$ & $\begin{array}{l}100 \\
100 \\
100 \\
100 \\
100 \\
100\end{array}$ & $\begin{array}{r}5 \\
10 \\
15 \\
20 \\
25 \\
30\end{array}$ & $\begin{array}{r}520 \\
250 \\
150 \\
100 \\
75 \\
75\end{array}$ & $\begin{array}{l}\text { Metallic } \\
\text { Metallic } \\
\text { Metallic } \\
\text { Too much formalin } \\
\text { Too much formalin } \\
\text { Too much formalin }\end{array}$ \\
\hline
\end{tabular}




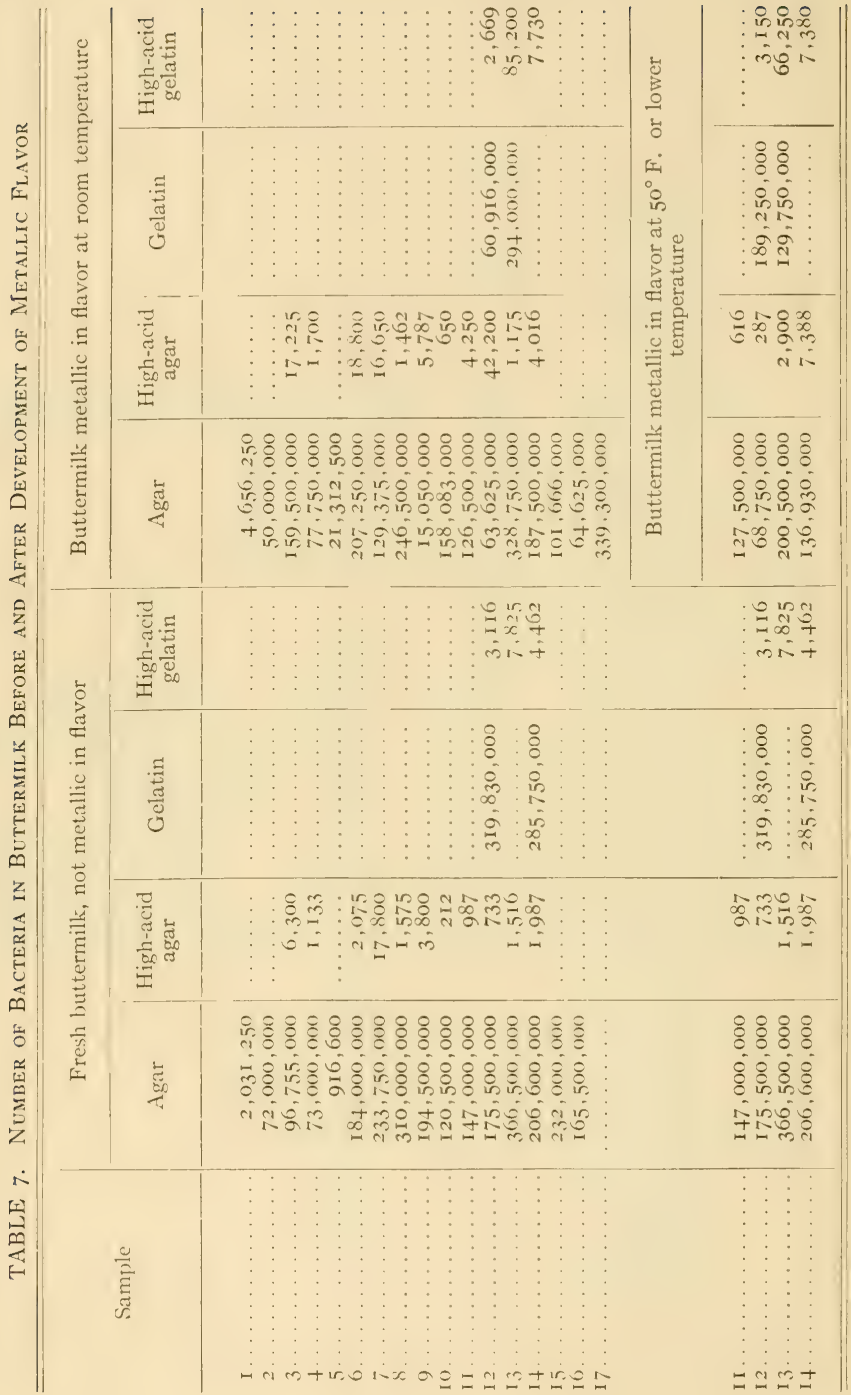


table 8. Ratios of Numbers of Bacteria in the High-Acid Agar and IN tHe Normal Agar

Sample




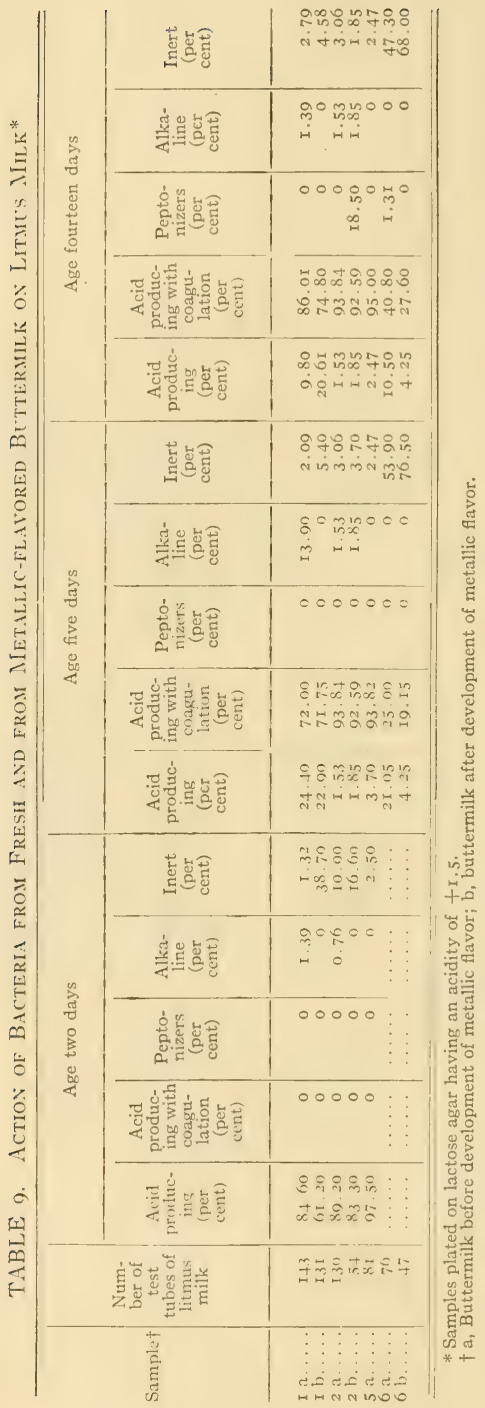


Metallic Flayor in Dairy Products

\begin{tabular}{|c|c|c|}
\hline \multirow{5}{*}{ 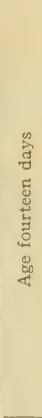 } & 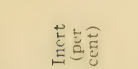 & 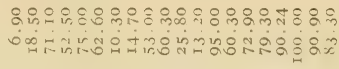 \\
\hline & & 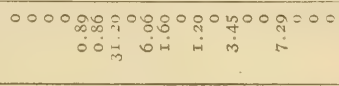 \\
\hline & & 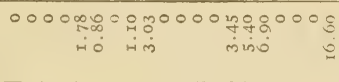 \\
\hline & 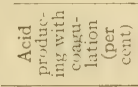 & $\begin{array}{c}\text { in } \\
0000000000000 \\
.\end{array}$ \\
\hline & 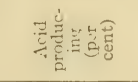 & 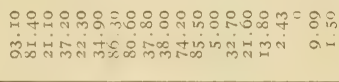 \\
\hline \multirow{5}{*}{ 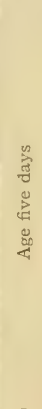 } & & 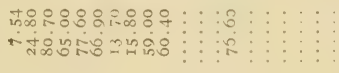 \\
\hline & & $00000000000 \vdots \vdots 0^{0} \vdots \vdots \vdots \vdots \vdots$ \\
\hline & & $\begin{array}{cc:c}0000000000 & \vdots \\
0 & \vdots & \vdots \\
0 & \vdots\end{array}$ \\
\hline & 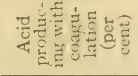 & 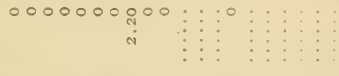 \\
\hline & 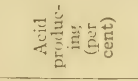 & 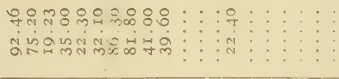 \\
\hline \multirow{5}{*}{ 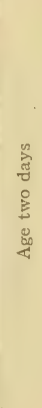 } & & 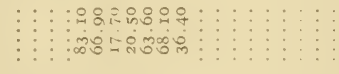 \\
\hline & & \\
\hline & 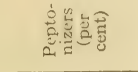 & 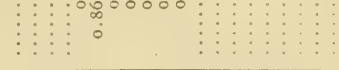 \\
\hline & 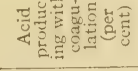 & \\
\hline & 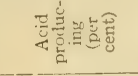 & 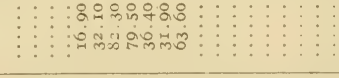 \\
\hline & 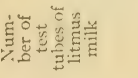 & 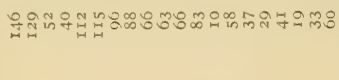 \\
\hline & 产 & 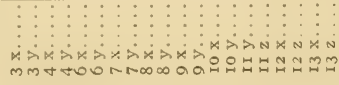 \\
\hline
\end{tabular}


TABle ir. Production of Metallic Flavor by inoculation

\begin{tabular}{|c|c|c|c|c|c|}
\hline \multirow{2}{*}{ Sample } & \multicolumn{5}{|c|}{ Judged by } \\
\hline & Ayres & Middaugh & Pickerill & Luce & Guthrie \\
\hline 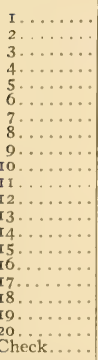 & 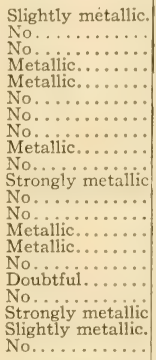 & 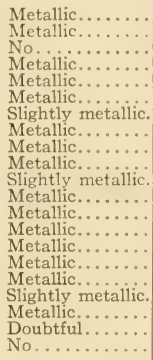 & 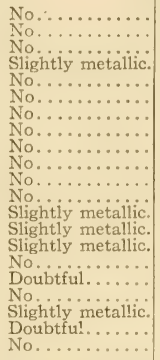 & 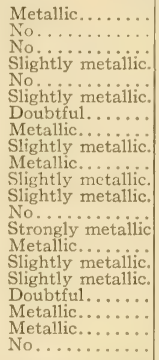 & $\begin{array}{l}\text { Slightly metallic } \\
\text { No } \\
\text { No } \\
\text { No } \\
\text { Slightly metallic } \\
\text { Slightly metallic } \\
\text { No } \\
\text { No } \\
\text { Slightly metallic } \\
\text { No } \\
\text { Metallic } \\
\text { Slightly metallic } \\
\text { Slightly metallic } \\
\text { Slightly metallic } \\
\text { Slightly metallic } \\
\text { Slightly metallic } \\
\text { No } \\
\text { No } \\
\text { Slightly metallic } \\
\text { Slightly metallic } \\
\text { No }\end{array}$ \\
\hline
\end{tabular}

TABlE 12. Production of Metallic Flavor by Inoculation

\begin{tabular}{|c|c|c|c|c|c|}
\hline \multirow{2}{*}{ Sample } & \multicolumn{5}{|c|}{ Judged by } \\
\hline & Ayres & Middaugh & Pickerill & Luce & Guthrie \\
\hline 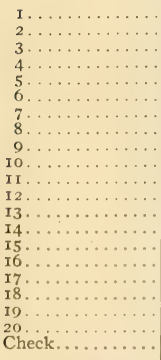 & 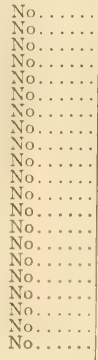 & 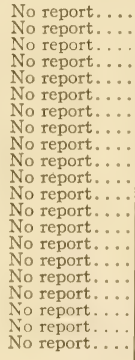 & 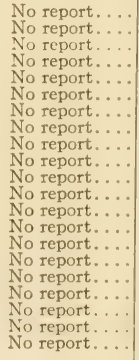 & 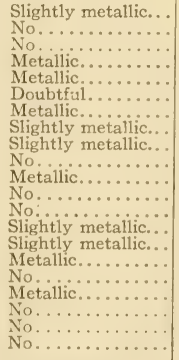 & $\begin{array}{l}\text { Slightly metallic } \\
\text { No } \\
\text { No } \\
\text { No } \\
\text { No } \\
\text { No } \\
\text { No } \\
\text { No } \\
\text { Slightly metallic } \\
\text { No } \\
\text { No } \\
\text { Slightly metallic } \\
\text { No } \\
\text { No } \\
\text { No } \\
\text { No } \\
\text { No } \\
\text { No } \\
\text { No } \\
\text { No } \\
\text { No }\end{array}$ \\
\hline
\end{tabular}


TABle 13. Production of Metallic Flavor by Inoculation

\begin{tabular}{|c|c|c|c|c|c|}
\hline \multirow{2}{*}{ Sample } & \multicolumn{5}{|c|}{ Judged by } \\
\hline & Ayres & Middaugh & Pickerill & Luce & Guthrie \\
\hline 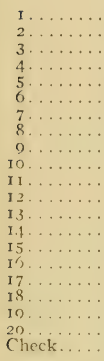 & 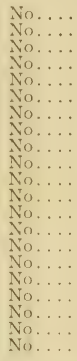 & 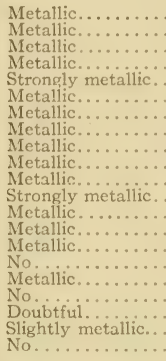 & 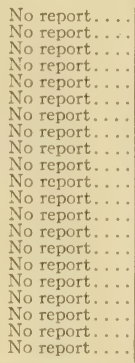 & 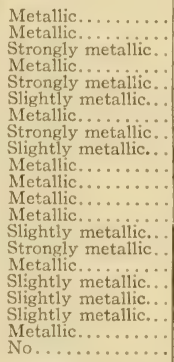 & $\begin{array}{l}\text { No } \\
\text { No } \\
\text { No } \\
\text { No } \\
\text { No } \\
\text { No } \\
\text { No } \\
\text { No } \\
\text { Slightly metallic } \\
\text { Slightly metallic } \\
\text { No } \\
\text { No } \\
\text { Slightly metallic } \\
\text { No } \\
\text { No } \\
\text { No } \\
\text { No } \\
\text { No } \\
\text { Doubtful } \\
\text { No } \\
\text { No }\end{array}$ \\
\hline
\end{tabular}

TABlE 14. Production of Metallic Flavor by Inoculation

\begin{tabular}{|c|c|c|c|c|c|}
\hline \multirow{2}{*}{ Sample } & \multicolumn{5}{|c|}{ Judged by } \\
\hline & Ayres & Middaugh & Pickerill & Luce & Guthrie \\
\hline 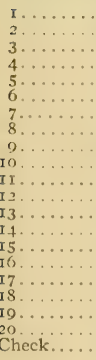 & 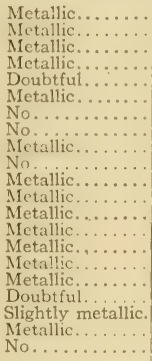 & 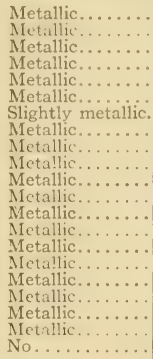 & 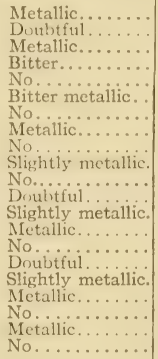 & 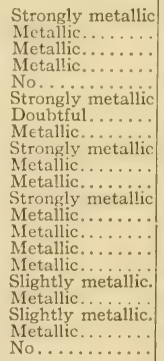 & $\begin{array}{l}\text { Metallic } \\
\text { Metallic } \\
\text { Slightly metallic } \\
\text { Slightly metallic } \\
\text { No } \\
\text { Metallic } \\
\text { No } \\
\text { Very metallic } \\
\text { Slightly metallic } \\
\text { Metallic } \\
\text { Slightly metallic } \\
\text { Metallic } \\
\text { Metallic } \\
\text { Slightly metallic } \\
\text { Metallic } \\
\text { Metallic } \\
\text { Slightly metallic } \\
\text { Metallic } \\
\text { Slightly metallic } \\
\text { Metallic } \\
\text { No }\end{array}$ \\
\hline
\end{tabular}


TABlE i5. Production of Metallic Flavor by Inoculation

\begin{tabular}{|c|c|c|c|c|c|}
\hline \multirow{2}{*}{ Sample } & \multicolumn{5}{|c|}{ Judged by } \\
\hline & Hepburn & Ayres & Pickerili & Luce & Guthrie \\
\hline 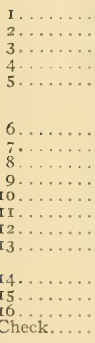 & 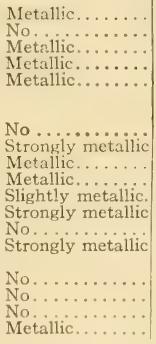 & 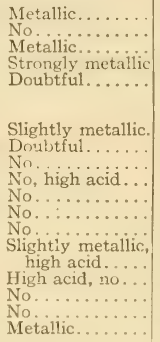 & 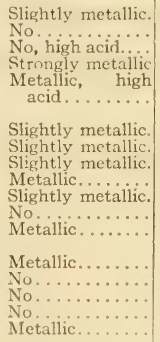 & $\begin{array}{l}\text { Slightly metallic. } \\
\text { No...........ilic } \\
\text { Strongly metallic } \\
\text { Strongly metallic } \\
\text { Slightly metallic. } \\
\text { Metallic......... } \\
\text { Slightly metallic. } \\
\text { Slightly metallic. } \\
\text { Slightly meta'lic. } \\
\text { Metallic......... } \\
\text { Metallic..... } \\
\text { Slightly metallic. } \\
\text { Slightly metallic. } \\
\text { Doubtful......... } \\
\text { No.............. } \\
\text { No............. } \\
\text { Strongly metallic }\end{array}$ & $\begin{array}{l}\text { Slightly metallic } \\
\text { Doubtful } \\
\text { Metallic } \\
\text { Strongly metallic } \\
\text { Slightly metallic, } \\
\text { overripe } \\
\text { Slightly metallic } \\
\text { No, overripe } \\
\text { Doubtful } \\
\text { Slightly metallic } \\
\text { Metallic } \\
\text { Metallic } \\
\text { Slightly metallic } \\
\text { Slightly metallic } \\
\text { No, overripe } \\
\text { No, overripe } \\
\text { No, overripe } \\
\text { Metallic }\end{array}$ \\
\hline
\end{tabular}




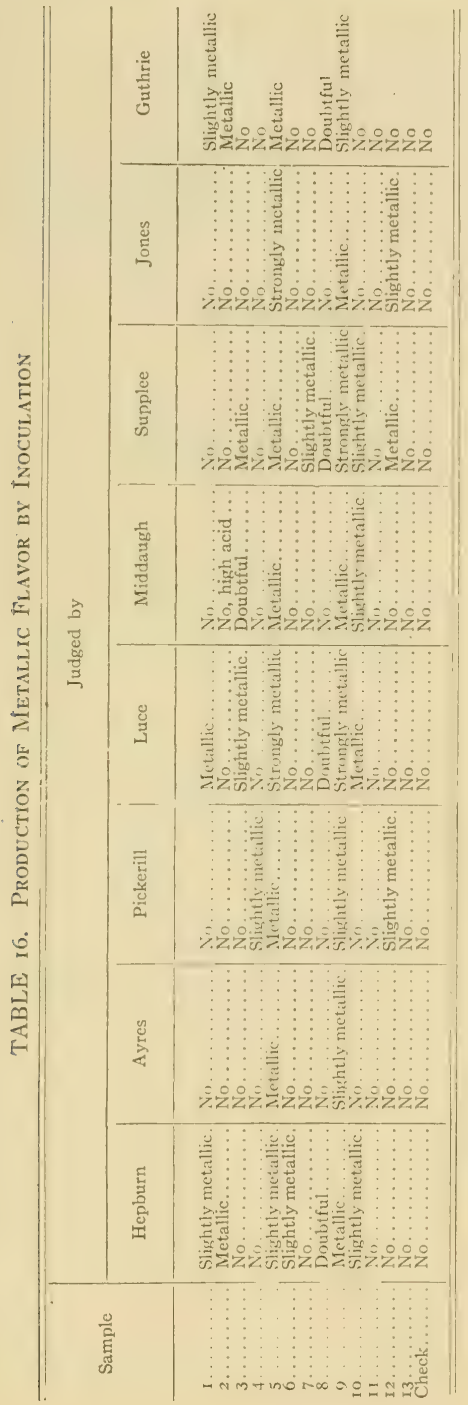




\begin{tabular}{|c|c|c|}
\hline \multirow[t]{2}{*}{$\stackrel{\Xi}{\Xi}$} & 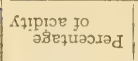 & 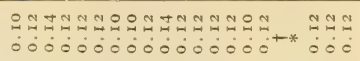 \\
\hline & ssautpnoiว & 111111111111111111111 \\
\hline \multirow{3}{*}{$\frac{\stackrel{.}{0}}{3}$} & 7uaurpas & ++++++++++++++++++++1 \\
\hline & 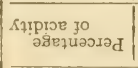 & 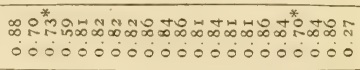 \\
\hline & ssau!pno|ว | & ++++++++++++++++++++1 \\
\hline \multirow{3}{*}{ 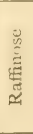 } & zuaunpas & 11111111111111111111 \\
\hline & 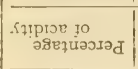 & 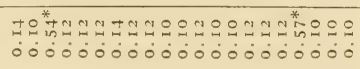 \\
\hline & ssautpnotว | & $11+11111111111111+111$ \\
\hline \multirow{3}{*}{ 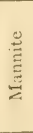 } & 7uวur!pas | & 111111111111111111111 \\
\hline & 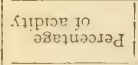 & 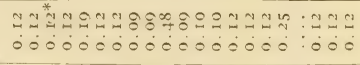 \\
\hline & ssวu!pno广ว & $111111111+111111+1111$ \\
\hline \multirow{3}{*}{$\begin{array}{l}\frac{\Xi}{0} \\
\frac{0}{0} \\
\frac{1}{0}\end{array}$} & zuautpas & 111111111111111111111 \\
\hline & 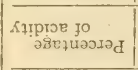 & 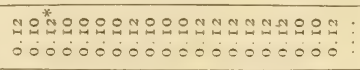 \\
\hline & ssau!pno|ว & $1.11+11 ! 111++111 ! 11111$ \\
\hline \multirow{3}{*}{ 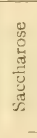 } & 7uaurpas & $11+1++11+111+1111+1+1$ \\
\hline & 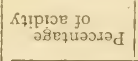 & 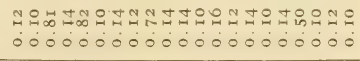 \\
\hline & ssaupnoj | & $11+1++11+111+1111+1+1$ \\
\hline \multirow{3}{*}{ 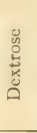 } & 7uaurpas & $1+++++++++++++++++++1$ \\
\hline & 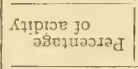 & 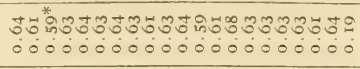 \\
\hline & ssau!pno广ว & ++++++++++++++++++++1 \\
\hline \multirow{3}{*}{ 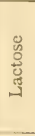 } & 7นวur!pas | & ++++++++++++++++++++1 \\
\hline & 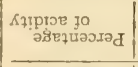 & 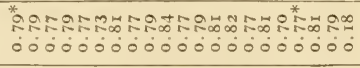 \\
\hline & ssautpnoюว & +11111111111111111111 \\
\hline \multicolumn{2}{|c|}{ 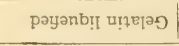 } & 111111111111111111111 \\
\hline \multicolumn{2}{|r|}{ papsno भाझा } & ++++++++++++++++++++1 \\
\hline & นolpewroy seg | & 111111111111111111111 \\
\hline & 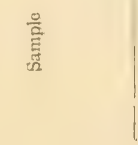 & Und \\
\hline
\end{tabular}




\begin{tabular}{|c|c|c|}
\hline \multirow[t]{2}{*}{ 点 } & 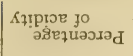 & 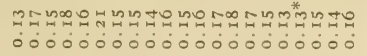 \\
\hline & ssəu!pnoiว & 1111111111111111111 \\
\hline \multirow{3}{*}{ 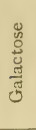 } & 7uәuाp & $+++t+++t++++++t++t+1$ \\
\hline & 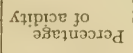 & 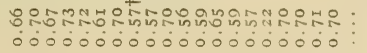 \\
\hline & ssaumpnoID & $t+t+t+t+t+t+t+t+t+1$ \\
\hline \multirow{3}{*}{ 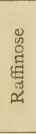 } & 7uәuцpas & 11111111111111111111 \\
\hline & 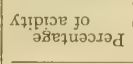 & 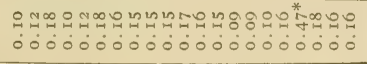 \\
\hline & ssou!pnois & 111111111111111111 \\
\hline \multirow{3}{*}{ 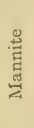 } & 7uau!pas & 1111111111111111111 \\
\hline & 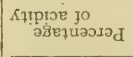 & 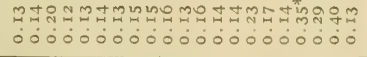 \\
\hline & ssəuipnoIว & 11111111111111111 \\
\hline \multirow{3}{*}{ 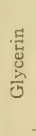 } & qu: :utpas & $1111 ! 111111 ! 11111111$ \\
\hline & 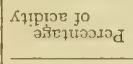 & 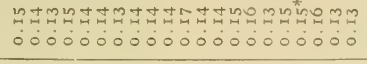 \\
\hline & ssau!pnotว & 11111111111111111 \\
\hline \multirow{3}{*}{ 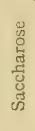 } & quatu!pas & 1111111111111111 \\
\hline & 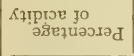 & 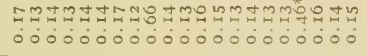 \\
\hline & ssoupnolo & $11111111+11111111111$ \\
\hline \multirow{3}{*}{$\begin{array}{l}\text { D } \\
\text { o } \\
\text { 苟 } \\
\text { 心్ }\end{array}$} & 7นวน!pว & $++++++t++t+t+t++t+1$ \\
\hline & 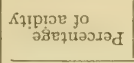 & 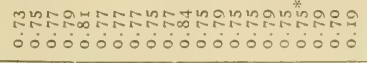 \\
\hline & ssaurpnoij & $1111111111+111111111$ \\
\hline \multirow{3}{*}{ 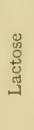 } & 7uวu!pas & $+++++++t+++++++++++t+$ \\
\hline & 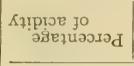 & 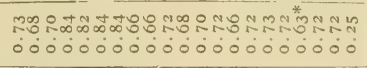 \\
\hline & ssau!pnoto & 111111111111111111 \\
\hline \multicolumn{2}{|c|}{ 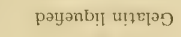 } & 11111111111111111111 \\
\hline & pəipın भI!W & +++++++++++++++++++1 \\
\hline & uoţeurof sey & 1111111111111111111 \\
\hline & 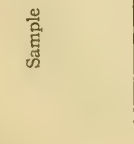 & 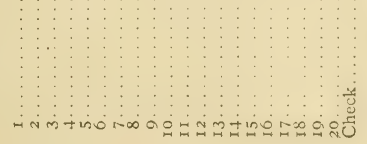 \\
\hline
\end{tabular}

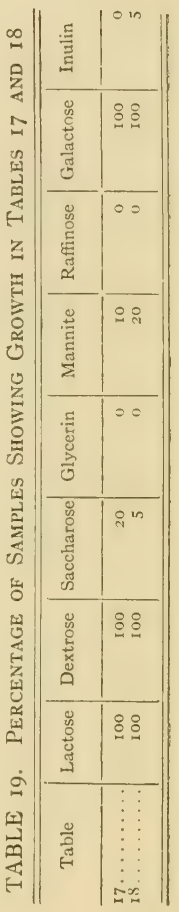




\title{
CORNELL UNIVERSITY AGRICULTURAL EXPERIMENT STATION
}

\author{
The Following Bllletins and Circulars Are Available for Distribution to \\ Residents of New York State Who May Desire Them
}

\section{BULLETINS}

226 An apple orchard survey of Wayne County

260 American varieties of beans

28.3 The control of insect pests and plant diseases

291 The apple redbugs

295 An agricultural survey of Tompkins County

307 An apple orchard survey of Cntario County

3 I3 The production of new and improved varieties of timothy

316 Frosts in New York

317 Further experiments on the economic value of root crops for New York

3 rs Constitutional vigor in poultry

320 Sweet-pea studies - III. Culture of the sweet pea

Cherry fruit-flies and how to control them

Hop mildew

Control of two elm-tree pests

A study of some factors influencing the yield and the moisture content of cheddar cheese

The Babcock test, with special reference to testing cream

Crop yields and prices, and our future food supply

\section{CIRCULARS}

Orange hawkweed, or paint brush

The chemical analysis of soil

Legume inoculation

The improved New York State gasolineheated colony-house brooding system

I7 The formation of cow-testing associations

Milking machines: their sterilization and their efficiency in producing clean milk The fire blight disease and its control in nursery stock

22
342

345

346

347

350

353

354

355

357

358

$36 \mathrm{I}$

364 apples in New York City for twenty years

Sweet-pea studies-IV. Classification of garden varieties of the sweet pea

A continued study of constitutional vigor in poultry

The tarnished plant-bug

Endothia canker of chestnut

Potato scab and sulfur disinfection

The interior quality of market eggs

Further experiments in the dusting and spraying of apples

Two factors causing variation in the weight of print butter

The cost of milk production

Some important leaf diseases of nursery stock The home grounds

Cost of producing milk on I74 farms in Delaware County, New York

Woodlot conditions in Broome County, New York

Woodlot conditions in Dutchess County, New York

Dusting and spraying experiments with apples Forest legislation in America prior to March 4, 1780

The leaf blotch disease of horse-chestnut

24 Some suggestions for city persons who desire to farm

26 Peach cankers and their treatment

28 Apple cankers and their contro!

29 Poultry parasites; some of the external parasites that infest domestic fowls, with suggestions for their control

30 Methods of making some of the soft cheeses

3I Fall spraying for peach leaf curl

32 Dusting nursery stock for the control of leaf diseases

\section{Address MAILING ROOM \\ COLLEGE OF AGRICULTURE ITHACA, NEW YORK}


$$
\text { . }
$$ 

L.

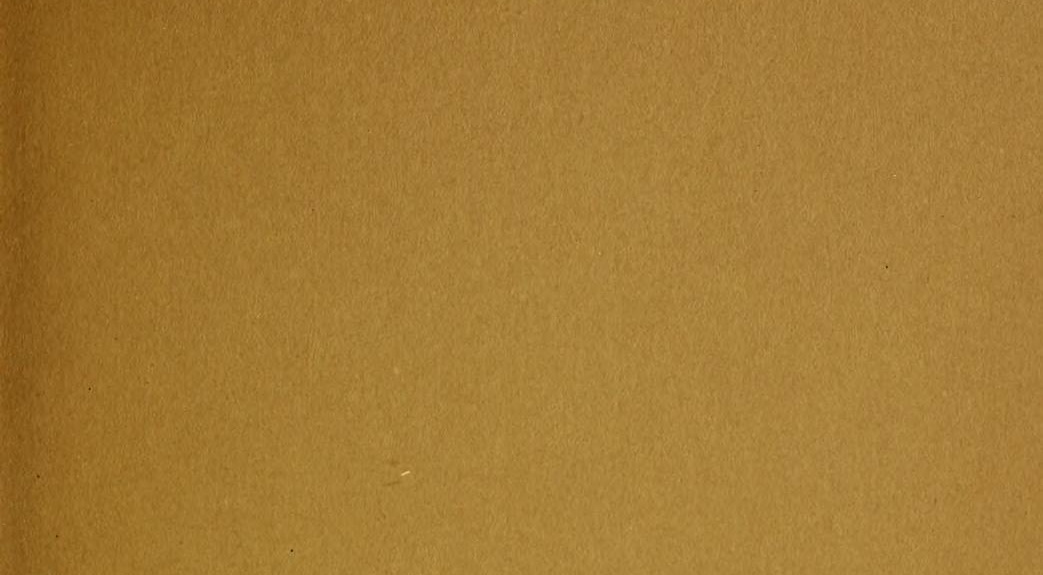

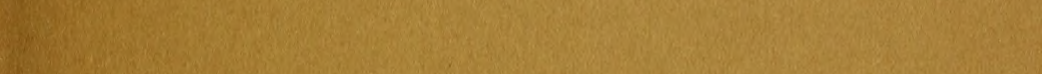

30

(2)

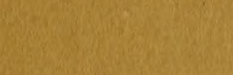

tety

and

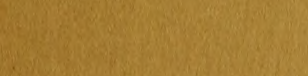

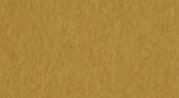

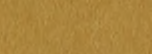

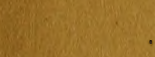

S.

S.

S.

S.

i.

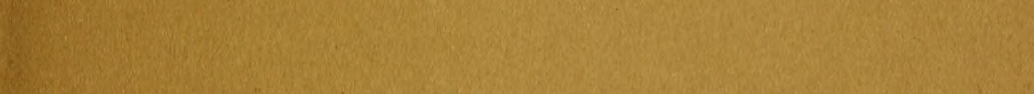

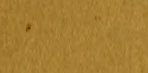

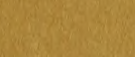

7.

23
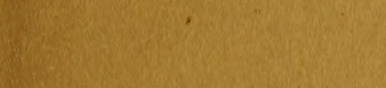

9. 3 (1)
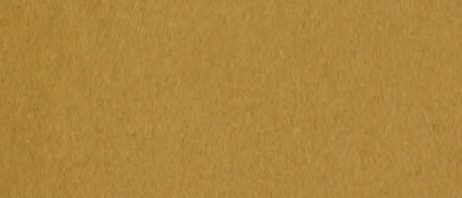

the

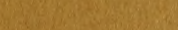

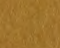

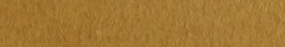


LIBRARY OF CONGRESS

00008952942 